\title{
Validation of the Argentinian Spanish version of the Transition Readiness Assessment Questionnaire for adolescents with chronic conditions
}

\author{
Florencia González, M.D. ${ }^{a}$, Mariana Roizen, M.D. ${ }^{a}$, \\ María de las Mercedes Rodríguez Celin, M.D. ${ }^{a}$, Carmen De Cunto, M.D. ${ }^{b}$, \\ Alfredo Eymann, M.D. ${ }^{b}$, Roberto Mato, M.D. ${ }^{a}$, Patricia García Arrigoni, M.D. ${ }^{a}$, \\ Raquel Staciuk, M.D. ${ }^{a}$, Florencia Ugo, B.S. ${ }^{a}$ and Virginia Fano, M.D. ${ }^{a}$
}

\begin{abstract}
Introduction. The transition of adolescents with chronic conditions to adult follow-up care is an increasingly complex process. Patients need to acquire knowledge and skills that ensure continuity of their care. The goal of this study was to validate the Argentinian Spanish version of the Transition Readiness Assessment Questionnaire (TRAQ) 5.0 tool in adolescents and young adults with chronic conditions.
\end{abstract}

Hospital Nacional de Pediatría "Prof. Dr. Juan P. Garrahan".

b. Department of Pediatrics, Hospital Italiano de Buenos Aires.

\section{E-mail address:}

Florencia González, M.D.: gonzalezfl@yahoo. com.ar

\section{Funding:}

Florencia González, M.D., received a research grant awarded by the Research Coordination Office and funded by Fundación Garrahan of the Hospital Nacional de Pediatría Prof. Dr. Juan P. Garrahan" in 2014 ("Development of a transition program for adolescent and young adult patients with chronic conditions in Hospital Garrahan: Laying the foundations") and 2015 ("Expansion of validation and assessment of the usefulness of TRAQ 5.0 tool and spreading of transition challenges at Hospital Garrahan").

Conflict of interest: None.

Received: 6-10-2016 Accepted: 9-26-2016

\section{INTRODUCTION}

Advances in health care over the last decades have led to increased survival of patients with complex pediatric conditions reaching adulthood.

These children have special health care needs, which, for the most part, persist as they grow up and become adults. ${ }^{1}$

The transition of these patients into follow-up care by adult health care providers is an increasingly common reality that should be organized hierarchically by the health team and seen as a process rather than as an isolated event. ${ }^{2}$ It is important to distinguish between transfer -understood as the single act of transferring the patient from one institution or care team to anotherand transition, defined as a dynamic, complex, planned process that includes patient transfer itself.

The transition process may be especially critical for disease outcomes. Some patients abandon medical follow-up care or treatment when they leave pediatric care, which puts their health at increased risk. ${ }^{3}$

Given the complexity of certain conditions, adolescents are required to acquire knowledge and skills that ensure continuity of their care. This must be a gradual process, as it is planned for identifying and implementing educational, medical and care resources from adult health care services. ${ }^{4,5}$

Available bibliography proposes that tools be administered in 
questionnaire format in order to assess patients' autonomy at the beginning of the transition process and at successive stages, and set progress milestones or identify challenges. ${ }^{5-7}$

To date, there was no validated tool available in Argentina. According to a bibliographic review, several tools have been made available-some are condition-specific while others are generic and can be used in patients with different chronic conditions. ${ }^{8}$ The generic tool that seems to be the most suitable one given its characteristics is the Transition Readiness Assessment Questionnaire (TRAQ). It is designed to measure transition readiness of youth with special health conditions. This tool was initially developed by investigators at the University of Florida, and validated for use in adolescents aged 14 years and older. Its latest original version, TRAQ 5.0, includes 20 items, and its validation showed good psychometric properties. ${ }^{9,10}$

The aim of this study was to validate the Argentinian Spanish version of the TRAQ 5.0 tool in adolescents and young adults with chronic conditions.

\section{POPULATION, MATERIAL AND METHODS POPULATION}

The study population comprised patients treated at the following departments of Hospital Nacional de Pediatría Garrahan, in some of its outpatient clinics (if applicable, these are mentioned between brackets): Growth \& Development, Gastroenterology (Inflammatory Bowel Diseases and Hepatology), Myelomeningocele, Pulmonology (Asthma, Chronic Obstructive Pulmonary Disease, Cystic Fibrosis of Pancreas, Lung Transplantation), Neurology (Neuromuscular Disease and Epilepsy), Nutrition (Diabetes), Oncology (Solid and Central Nervous System Tumors), Liver and Bone Marrow Transplantation.

At a first stage, patients aged 16 years or older who had successfully completed fifth grade of primary school between July 2014 and June 2015 were included. At a second stage, in line with the original tool, validation was extended to patients aged 14 years to 15 years and 11 months, from August 2015 to November 2015..$^{10}$

Recruitment was conducted by consecutive and convenience sampling, and patients who had had any type of contact for follow-up care with an adult health care provider were excluded.

Informed consent was obtained from patients and their parents or families. The study was approved by both the Ethics and the Teaching and Research Committees.

\section{TOOLS}

Transition Readiness Assessment Questionnaire 5.0, Argentinian Spanish Version

The TRAQ 5.0 questionnaire includes 20 items divided into 5 subscales: A. Managing Medication; B. Appointment Keeping; C. Tracking Health Issues; D. Talking with Providers; and E. Managing Daily Activities. Each item is rated 1 to 5 on a Likert scale, where 1 is minimum autonomy and 5 is maximum autonomy. Overall and subscale scores correspond to the average score of answered items. The questionnaire is designed to be self-administered (Annex).

The transcultural adaptation into Argentinian Spanish was made by a research team of Hospital Italiano de Buenos Aires, and its latest version was approved by the authors of the original tool (paper in preparation). The last stage of the transcultural adaptation process, in which comprehensibility of the local version was fieldtested, as well as the validation process discussed in this article, incorporated patients from Hospital Garrahan and were undertaken by a work group made up of investigators from both hospitals.

\section{Supplementary questionnaire completed by patients}

This was an opinion survey in which participants were asked about their experience completing the TRAQ.

To assess the patients' outlook on the future, two questions were added: "Where do you see yourself in 5 years? And in 10 years?".

\section{Visual analogue scales}

Figure 1 shows the visual analogue scales (VAS) administered to physicians and their patients after completing the TRAQ. To assess the degree of health impairment, primary care physicians were asked to rate the severity of the disease and/or current disease activity, as appropriate, on a 0 to 10 scale (from "no impairment" to "maximum impairment"). For an additional assessment of patient readiness, patients were asked to rate their self-perceived readiness on a global 0-10 scale (from "not at all ready" to "totally ready").

\section{Supplementary questionnaire completed by the investigator}

The investigator in charge of the interviews 
recorded several socio-demographic, clinical and TRAQ administration-related variables.

Data supplied by parents were age, sex, place of residence, patient's and parents' schooling level, health insurance and subsidy, patient's current engagement in an activity and socio-economic level as established by the unmet basic needs (UBN) index, a direct method for measuring structural poverty. This is determined by the presence of at least one of the following conditions: overcrowding (more than 3 inhabitants per room), school attendance (households with at least one 6-12-year-old child not attending school), housing and sanitation (tenement house, substandard housing, without a flush toilet), and subsistence capacity (households with 4 or more people per employed house member and whose head has not completed the second grade). ${ }^{11}$ A patient was deemed to be currently engaged in an activity if he/she was working, studying, or had a dependent relative.

Medical data were obtained from clinical records and/or primary care physicians: diagnosis, comorbidities, involved organs, main follow-up team, specializations engaged in follow-up, history of the condition, current treatment and number of follow-up visits, emergency room visits and hospitalizations within the last year.

To assess TRAQ administration feasibility, the investigator recorded fill-out time and ability to fill it out, need for help (minimum: $<4$ times; significant: $\geq 4$ times), form of administration, and difficulties due to the questionnaire's format or with any of the questionnaire's items.

\section{Design}

Descriptive, cross-sectional, quantitative study. One of the physician investigators (GF), who was not related to patient follow-up, was in charge of administering the tool.

Construct validity was analyzed by testing different hypotheses, where changes in TRAQ scoring according to age, sex, severity of the condition and plans for the future were evaluated, as well as the scoring changes in comparison to another scale.

We further examined the feasibility and validity of TRAQ discrimination by socioeconomic level, health coverage, education level, and condition-specific follow-up group.

\section{Strategy}

Based on the organization of each outpatient clinic, we checked if any patients aged 14 years or older had visits scheduled; we asked the primary care physicians if it was possible to include them in the study, and patients were invited to participate, usually at the waiting room. Patients were asked to complete the TRAQ in a selfadministered modality, as well as the opinion survey and the VAS of global self-perceived health care readiness, and they were allowed to ask for the investigator's assistance. At the same time, the socio-demographic, clinical and TRAQ administration-related data were recorded. Finally, the primary care physician was asked to complete the VAS on the patients' current health impairment.

FIGURE 1. Visual analogue scales administered to patients and their physicians

VAS of degree of health impairment due to the condition (reported by primary care physician)

$\begin{array}{cccccccccr}0 & 1 & 2 & 3 & 4 & 5 & 6 & 7 & 8 & 9 \\ \text { No impairment }\end{array}$

VAS of transition readiness (reported by patient)

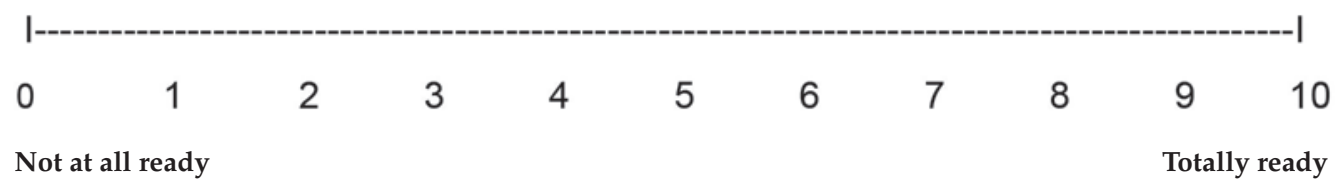




\section{Statistical analysis}

To assess administration feasibility, we set an $a$ priori condition that the tool should be understood by at least $80 \%$ of the participants. Questionnaires were considered lost if the respondent was not able to answer more than $50 \%$ of items, even after getting help. The challenges faced, median time and help needed for completion, as well as its association with the education level and poverty (UBNs), were described using Fisher's test or $\chi^{2}$ test. It was considered that a child's education level was lower than the one expected for his/her age if there was a $\geq 2$-year difference in comparison to what would be the appropriate school level for the patient's age or special education.

Score distribution was described through means, standard deviation (SD), ranges and floor/ceiling effects for each score/domain. Floor or ceiling effect was deemed to be present if more than $15 \%$ of participants had used extreme values. ${ }^{12}$

Scale reliability was assessed by determining the internal consistency of the tool using Cronbach's alpha for the overall score and each subscale score, considering a value of 0.70 and a value of 0.90 as the limits for group comparison and for individual analysis, respectively.

Patients' responses in relation to their plans for the future were analyzed by the 3 main investigators and, based on their contents, they were dichotomized as "with plans" or "without plans" for the future.

Discriminant validity was analyzed on the basis of the differences in scores amongst patients' sex, current engagement in an activity and outlook on the future. An exploratory analysis was also carried out to check for differences according to UBNs, education level, and followup group. We used the t-test for independent samples or the analysis of variance (ANOVA) for dichotomous or categorical variables, respectively.

Correlation between TRAQ results and age, health impairment due to the condition, and perceived transition readiness was determined using Pearson's test.

For analyses, statistical significance was set at $p<0.05$. The SPSS11.5 software was used for data processing.

Results were reported globally, only discriminating groups by age (14-16 years old and more than 16 years old) if significant differences were found.

\section{RESULTS}

At the first stage, out of 142 patients invited to participate, 2 were not included: one due to time constraints and the other one because he later declined to participate. At the second stage, out of 54 patients invited to participate, 3 decided not to participate. A total of 191 patients were enrolled.

Table 1 shows socio-demographic characteristics. Sex distribution was homogeneous. Mean age was 16.9 years (SD: 1.57), with a broad age range that reached the age of 26 years. Most patients lived outside the province of Buenos Aires. Almost $50 \%$ of them had obtained a disability certificate, while $25 \%$ did not have appropriate school level for their age.

\section{Feasibility}

The results of the TRAQ 5.0 feasibility assessment are shown on Table 2 .

Overall, the tool was well understood and was completed in a short time. There were no major difficulties as far as format was concerned.

Only $7(3.7 \%)$ participants were unable to complete it. Three of them had a diagnosis of intellectual disability; two had long-term home schooling due to an underlying condition; one had a special education aide, and the other one had dropped out of school more than 5 years earlier.

Out of the 184 patients who were able to complete the questionnaire, $81 \%$ did it without help. Of the $19 \%$ of patients who did need help, only 3 received statistically significant assistance. It was noted that patients with UBNs or ageinappropriate education level needed more help (patients with UBNs: $36.4 \%$ versus patients without UBNs: $16.7 \%, p=0.027$; patients with age-inappropriate education level: $36.6 \%$ versus patients with age-appropriate education level: $13.9 \%, p=0.001$ ).

Most patients were able to self-administer the questionnaire. Only in 12 cases was the questionnaire administered by the investigator: 8 due to muscle weakness, 3 due to visual impairments, and 1 because of reading difficulties.

Based on the patients' opinion, the majority liked responding the questionnaire $(67.9 \%)$, and the questions were easy to answer $(62 \%)$ and relevant (79.9\%). Thirty-eight percent (38\%) responded that they had been asked something new, something they had not thought of before.

\section{Score distribution}

Table 3 describes score distribution. All 
patients used the complete range of options for all 20 items. Except for the Talking with Providers and Managing Daily Activities domains, where the ceiling effect was moderate, the floor and ceiling effects were null or minimum in the remaining domains and for the overall score. This distribution ensures that the options offered by the tool cover the spectrum of options required for the population.

\section{Reliability}

From Table 3 it can be seen that Cronbach's alpha coefficient of reliability for the overall score was 0.81 . Subscale score reliability, however, is below the recommended minimum of 0.7 , except for Appointment Keeping domain, which indicates that the tool should only be used for making comparisons from its overall score.

\section{Validity}

Construct and discriminant validities of the tool were assessed by testing the formulated hypotheses (Table 4):

1. There was positive correlation between age and the overall TRAQ score $(r=0.286$; $p<0.001)$, and differences were found when scores were compared by age group.

2. Women had better scores than men.

3. There was negative correlation, albeit not statistically significant, between the overall

TABLE 1. Socio-demographic characteristics of the population included in the validation of the Transition Readiness Questionnaire 5.0, Argentinian Spanish version

\begin{tabular}{|l|l|l|}
\hline & N & Mean (SD)/\% \\
\hline Age & 191 & $16.9(1.57)$ \\
\hline Gender & 100 & $52.4 \%$ \\
$\quad$ Female & 91 & $47.6 \%$ \\
\hline Male & & \\
\hline Place of residence & 114 & $59.7 \%$ \\
$\quad$ Province of Buenos Aires & 14 & $7.3 \%$ \\
$\quad$ Autonomous City of Buenos Aires & 60 & $31.4 \%$ \\
$\quad$ Rest of the country & 3 & $1.6 \%$ \\
$\quad$ Paraguay & 24 & $12.6 \%$ \\
\hline Unmet basic needs & 55 & $28.8 \%$ \\
\hline No health coverage & & \\
\hline Health subsidy & 78 & $40.8 \%$ \\
$\quad$ None & 82 & $42.9 \%$ \\
$\quad$ Disability pension (includes disability certificate) & 31 & $16.2 \%$ \\
$\quad$ Disability certificate & & \\
\hline Education level & 145 & $75.9 \%$ \\
$\quad$ Appropriate for patient's age & 46 & $24.1 \%$ \\
$\quad$ Not appropriate for patient's age & & \\
\hline Type of education & 174 & $91.1 \%$ \\
$\quad$ Regular & 10 & $5.2 \%$ \\
Regular with integration & 4 & $2.1 \%$ \\
Home schooling & 2 & $1 \%$ \\
Special education due to intellectual disability & 1 & $0.5 \%$ \\
$\quad$ Special education due to motor involvement & & \\
\hline
\end{tabular}

1. Education level: A limit was set considering a $\geq 2$-year difference in comparison to what would be the appropriate school level for the patient's age or special education.

SD: Standard deviation. 
score and the degree of health impairment due to the condition (VAS) only in the group of patients aged 16 years and older.

4. Patients' global self-perceived readiness (VAS) correlated positively with the overall score.

5. Patients who had plans for the future or a positive outlook on the future had better scores than those who did not. Differences were not significant in the 14-16-year-old group.

Finally, in exploring whether the TRAQ results discriminated by UBNs, health coverage, ageappropriate education level and recruitment group, we only found differences in the latter variable.

Table 5 shows the relation between scores and the different recruitment groups. Significant differences are found between the overall score and the Managing Medication, Appointment Keeping and Managing Daily Activities domains. The Neurology group was found to be different, with lower self-reported readiness levels.

\section{DISCUSSION}

The Argentinian Spanish version of the TRAQ 5.0 was comprehensible and feasible to use in the population of adolescents/young adults with chronic conditions aged 14 years or older treated at a high-complexity hospital. It was easy to administer and required a short time for completion.
Although most participants completed it without help, the group of patients who did require help was more likely to have a history of intellectual disability or an education level that was not appropriate for their age, or belong to poor families. This need for help had already been verified in a prior study aimed to validate a quality of life assessment tool (PedsQL 4.0) in a similar population from the same hospital. ${ }^{13}$

As far as psychometric properties are concerned, the tool showed good internal consistency for overall score with Cronbach's alpha coefficient, which exceeded the recommended limit for group comparison (0.70). In comparison to the latest version published by the authors of the tool in 2014, Cronbach's alpha coefficients were lower for both the overall score (0.94 vs. 0.81$)$ and the different domains considered separately. ${ }^{10}$

The hypotheses formulated a priori were tested and the tool was shown to be valid for the global population. Sex and age-related hypotheses had also been assessed in the original questionnaire validation and their results match.

Although the authors of the original article had tested construct validity by checking for a relationship with patients' ethnicity and the presence of health coverage, in the local experience, it was decided not to consider these two variables as these differences are not often found in our population.

TAble 2. Administration of the Transition Readiness Assessment Questionnaire 5.0 in Argentinian Spanish: Difficulties, time and help needed for completion in adolescents/young adults. N: 191

\begin{tabular}{|c|c|c|}
\hline \multicolumn{2}{|c|}{ Aspect assessed } & \\
\hline \multicolumn{2}{|l|}{ Was able to complete it } & $96.3 \%$ \\
\hline \multirow[t]{3}{*}{ Help needed $^{1}$} & No help & $81 \%$ \\
\hline & Minimum $^{2}$ & $17.4 \%$ \\
\hline & Significant $^{2}$ & $1.6 \%$ \\
\hline \multirow[t]{2}{*}{ Mode of administration $^{1}$} & Adequate & $93.5 \%$ \\
\hline & Administered by investigator & $6.5 \%$ \\
\hline \multirow[t]{3}{*}{ Difficulties with format $^{1}$} & No difficulties & $83.7 \%$ \\
\hline & Forgot & $7.6 \%$ \\
\hline & Wrote over other items & $8.7 \%$ \\
\hline \multicolumn{2}{|c|}{ Time for completion ${ }^{1}$ (median) } & 5 minutes $(3-20)$ \\
\hline
\end{tabular}

1. For these estimates, only the group of patients who were able to complete the questionnaire was considered $(n=184)$. 2. Minimum help was deemed to be $<4$ times; significant, $\geq 4$ times. 
In addition, in the present experience, the TRAQ results were tested using two new hypotheses. The first one analyzed the correlation between TRAQ scores and a global external measure of self-perceived readiness (VAS), which reinforced the validity of this tool. ${ }^{13}$ The second one was aimed at determining whether there was consistency between health impairment due to the condition and TRAQ results. The lack of correlation in this study should be analyzed in future research, as this was an exploratory hypothesis that had not been used before.

It is important to note that one limitation of this study is that it was validated with a population recruited from only one hospital and in a lower number of patients, as opposed to the original study, in which patients were recruited from three different facilities. Hospital Garrahan, however, serves a heterogeneous population of patients, and the possibility of incorporating patients treated at Hospital Italiano in a second stage is being considered. The assessment of sensitivity to change in relation to the tool remains pending; this is a useful indicator to be employed in longitudinal studies to assess interventions.

In sum, the TRAQ 5.0 is available to assess the degree of readiness of Argentinian patients with chronic conditions aged 14 years and older. Future studies will determine whether it is a useful tool in the transition of adolescents with chronic conditions to adult health care.

\section{Acknowledgments}

We express our appreciation to the children who participated in the study and their families, as well as to the professionals who serve at the different departments of the hospital where this study was conducted.

TABle 3. Description of score distribution and reliability in the Transition Readiness Assessment Questionnaire 5.0, Argentinian Spanish version $(n=184)$

\begin{tabular}{|c|c|c|c|c|c|c|c|c|}
\hline \multirow[t]{2}{*}{ Score/Domain } & \multirow[t]{2}{*}{ Mean } & \multirow[t]{2}{*}{ SD } & \multirow[t]{2}{*}{ Range } & \multirow{2}{*}{$\begin{array}{l}\text { Floor } \\
\text { Effect } \\
\%\end{array}$} & \multirow{2}{*}{$\begin{array}{l}\text { Ceiling } \\
\text { Effect } \\
\%\end{array}$} & \multicolumn{3}{|c|}{ Cronbach $\alpha$ Coefficient } \\
\hline & & & & & & \begin{tabular}{|l|} 
From ages 14 \\
to 15 years and \\
11 months \\
$(n=49)$
\end{tabular} & $\begin{array}{l}\geq 16 \text { years } \\
\text { old }(n=135)\end{array}$ & $\begin{array}{l}\text { Total } \\
(n=184)\end{array}$ \\
\hline Total & 3.26 & 0.64 & $1.1-4.70$ & 0.5 & 0.5 & 0.81 & 0.80 & 0.81 \\
\hline Managing Medication & 3.63 & 0.91 & $1-5$ & 1.1 & 6.7 & 0.68 & 0.58 & 0.61 \\
\hline Appointment Keeping & 2.63 & 0.81 & 1-4.71 & 2.7 & 0.5 & 0.62 & 0.71 & 0.71 \\
\hline Tracking Health Issues & 2.96 & 0.89 & $1.25-4.75$ & 2.7 & 1.1 & 0.38 & 0.25 & 0.30 \\
\hline Talking with Providers & 4.19 & 0.98 & $1-5$ & 2.2 & 41.3 & 0.45 & 0.54 & 0.52 \\
\hline $\begin{array}{l}\text { Managing } \\
\text { Daily } \\
\text { Activities }\end{array}$ & 4.03 & 0.93 & $1-5$ & 1.6 & 23.9 & 0.63 & 0.51 & 0.55 \\
\hline
\end{tabular}

Note: Floor or ceiling effect was deemed to be present if it was greater than $15 \%$. Their magnitude is designated as minimum (0.20), moderate (0.50), and large (0.80).

SD: Standard deviation. 
TABLE 4. Construct validity of the Transition Readiness Assessment Questionnaire 5.0, Argentinian Spanish version

\begin{tabular}{|c|c|c|c|c|c|c|c|c|c|}
\hline \multicolumn{10}{|c|}{$1^{\text {st }}$ hypothesis: "Scores will improve with age." } \\
\hline & \multicolumn{3}{|l|}{$14-15$ years old } & \multicolumn{4}{|c|}{$\geq 16$ years old } & \multicolumn{2}{|l|}{ P* } \\
\hline Overall TRAQ score & \multicolumn{3}{|l|}{$3.01 \pm 0.65$} & \multicolumn{4}{|c|}{$3.34 \pm 0.61$} & \multicolumn{2}{|l|}{0.002} \\
\hline \multicolumn{10}{|c|}{$2^{\text {nd }}$ hypothesis: "Women will exhibit better results than men." } \\
\hline & $\begin{array}{l}\text { Overall score } \\
14-15 \text { years old }\end{array}$ & \multicolumn{2}{|c|}{$\mathbf{P}^{*}$} & \multicolumn{2}{|c|}{$\begin{array}{l}\text { Overall score } \\
\geq 16 \text { years old }\end{array}$} & \multicolumn{2}{|l|}{$\mathbf{P}^{*}$} & \begin{tabular}{|l|} 
Overall global \\
score
\end{tabular} & P* \\
\hline Women & $3.21 \pm 0.58$ & \multirow{2}{*}{\multicolumn{2}{|c|}{0.023}} & \multirow{2}{*}{\multicolumn{2}{|c|}{\begin{tabular}{|l|}
$3.44 \pm 0.55$ \\
$3.24 \pm 0.66$
\end{tabular}}} & \multirow{2}{*}{\multicolumn{2}{|c|}{0.057}} & $3.38 \pm 0.57$ & \multirow[t]{2}{*}{0.006} \\
\hline Men & $2.79 \pm 0.67$ & & $3.24 \pm 0.66$ & & & & & $3.12 \pm 0.69$ & \\
\hline \multicolumn{10}{|c|}{$\begin{array}{l}3^{\text {rd }} \text { hypothesis: "Patients with chronic conditions with higher level of severity or current activity will } \\
\text { have lower scores." }\end{array}$} \\
\hline & \multicolumn{2}{|c|}{\begin{tabular}{l|l} 
Overall TRAQ 5.0 \\
Score Mean (SD)
\end{tabular}} & \multicolumn{3}{|c|}{$\begin{array}{l}\text { Physician VAS } \\
\text { Mean (SD) }\end{array}$} & \multicolumn{2}{|l|}{$\mathbf{r}$} & \multicolumn{2}{|l|}{$p^{* *}$} \\
\hline 14-15 years old & \multicolumn{2}{|l|}{$3.01(0.65)$} & \multicolumn{3}{|c|}{$4.80(2.62)$} & \multicolumn{2}{|c|}{0.064} & \multicolumn{2}{|l|}{0.67} \\
\hline$\geq 16$ years old & \multicolumn{2}{|l|}{$3.34(0.61)$} & & $77(2.79)$ & & -0. & & 0.054 & \\
\hline Global & $3.26(0.64)$ & & & $78(2.74)$ & & -0. & 107 & 0.153 & \\
\hline $\begin{array}{l}4^{\text {th }} \text { hypothesis: "The } \\
\text { will be consistent." }\end{array}$ & patient's perceive & d tran & & $n$ readiness $a$ & & & & VAS and TRAQ & results \\
\hline & $\begin{array}{l}\text { Overall Score } \\
\text { TRAQ } 5.0 \\
\text { Mean (SD) }\end{array}$ & & $\begin{array}{l}\text { ent } \\
\text { an } 1\end{array}$ & $\begin{array}{l}\text { VAS } \\
\text { (SD) }\end{array}$ & $r$ & & & $p^{* *}$ & \\
\hline 14-15 years old & $3.01(0.65)$ & & $(3$. & .24) & 0.3 & & & 0.024 & \\
\hline$\geq 16$ years old & $3.34(0.61)$ & & $(2$. & .45) & 0.5 & & & $<0.001$ & \\
\hline Global & $3.26(0.64)$ & & $(2$ & $.81)$ & 0.4 & & & $<0.001$ & \\
\hline $\begin{array}{l}5^{\text {th }} \text { hypothesis: "Patie } \\
\text { have higher scores." }\end{array}$ & ents who are activ & vely en & & ed in an activ & ity o & rhav & & s for the future & will \\
\hline & $\begin{array}{l}\text { Overall score } \\
14-15 \text { years old }\end{array}$ & P* & & $\begin{array}{l}\text { verall score } \\
16 \text { years old }\end{array}$ & P* & & Ove & rall global score & p* \\
\hline $\begin{array}{l}\text { With plans for the } \\
\text { future ( } 5 \text { years) }\end{array}$ & $3.19 \pm 0.72$ & 0.49 & & $49 \pm 0.55$ & 0.0 & & 3.42 & \pm 0.60 & 0.004 \\
\hline \begin{tabular}{|l|} 
Without plans for \\
the future ( 5 years)
\end{tabular} & $3.03 \pm 0.53$ & & & $17 \pm 0.64$ & & & 3.14 & \pm 0.62 & \\
\hline $\begin{array}{l}\text { With plans for the } \\
\text { future (10 years) }\end{array}$ & $3.23 \pm 0.76$ & 0.44 & & $48 \pm 0.52$ & 0.0 & & 3.43 & \pm 0.58 & 0.019 \\
\hline \begin{tabular}{|l|} 
Without plans for \\
the future (10 years)
\end{tabular} & $3.05 \pm 0.57$ & & & $25 \pm 0.66$ & & & 3.20 & \pm 0.64 & \\
\hline
\end{tabular}

* t-Test. ** Analysis of Variance (ANOVA).

TRAQ: Transition Readiness Assessment Questionnaire; SD: Standard Deviation; VAS: Visual analogue scale. 
TABLE 5. Description of results of the Transition Readiness Assessment Questionnaire 5.0 by recruitment source

\begin{tabular}{|c|c|c|c|c|c|c|c|c|c|c|c|}
\hline \multirow[t]{2}{*}{ Score/Domain } & $\begin{array}{l}\text { G\&D } \\
(n=24)\end{array}$ & $\begin{array}{l}B M T \\
(n=11)\end{array}$ & $\begin{array}{l}\text { Pulmo. } \\
(n=34)\end{array}$ & $\begin{array}{l}\text { Onco. } \\
(n=26)\end{array}$ & $\begin{array}{l}M M C \\
(n=19)\end{array}$ & $\begin{array}{l}D B T \\
(n=20)\end{array}$ & $\begin{array}{l}\text { Gastro. } \\
(n=23)\end{array}$ & $\begin{array}{l}\text { Neuro. } \\
(n=21)\end{array}$ & \begin{tabular}{|l} 
Liver Tx \\
$(n=20)$
\end{tabular} & \multirow[t]{2}{*}{$f$} & \multirow[t]{2}{*}{$\mathrm{P}^{*}$} \\
\hline & $\begin{array}{l}\text { Mean } \\
\pm S D\end{array}$ & $\begin{array}{l}\text { Mean } \\
\pm \text { SD }\end{array}$ & $\begin{array}{l}\text { Mean } \\
\pm S D\end{array}$ & $\begin{array}{l}\text { Mean } \\
\pm \text { SD }\end{array}$ & $\begin{array}{l}\text { Mean } \\
\pm S D\end{array}$ & $\begin{array}{l}\text { Mean } \\
\pm \text { SD }\end{array}$ & $\begin{array}{l}\text { Mean } \\
\pm S D\end{array}$ & $\begin{array}{l}\text { Mean } \\
\pm S D\end{array}$ & $\begin{array}{l}\text { Mean } \\
\pm S D\end{array}$ & & \\
\hline Overall & $\begin{array}{l}3.16 \pm \\
0.59\end{array}$ & $\begin{array}{l}3.52 \pm \\
0.60\end{array}$ & $\begin{array}{l}3.12 \pm \\
0.54\end{array}$ & $\begin{array}{l}3.49 \pm \\
0.74\end{array}$ & $\begin{array}{l}2.94 \pm \\
0.63\end{array}$ & $\begin{array}{l}3.64 \pm \\
0.59\end{array}$ & $\begin{array}{l}3.26 \pm \\
0.51\end{array}$ & $\begin{array}{l}2.78 \pm \\
0.67\end{array}$ & $\begin{array}{l}3.35 \pm \\
0.64\end{array}$ & 3.85 & $<0.001^{1}$ \\
\hline $\begin{array}{l}\text { Managing } \\
\text { Medication }\end{array}$ & $\begin{array}{l}3.40 \pm \\
0.79\end{array}$ & $\begin{array}{l}3.88 \pm \\
1.02\end{array}$ & $\begin{array}{l}3.54 \pm \\
0.77\end{array}$ & $\begin{array}{l}4.04 \pm \\
0.99\end{array}$ & $\begin{array}{l}3.19 \pm \\
1.04\end{array}$ & $\begin{array}{l}4.00 \pm \\
0.70\end{array}$ & $\begin{array}{l}3.69 \pm \\
0.77\end{array}$ & $\begin{array}{l}3.10 \pm \\
1.09\end{array}$ & $\begin{array}{l}3.56 \pm \\
0.93\end{array}$ & 2.48 & $0.015^{2}$ \\
\hline $\begin{array}{l}\text { Appointment } \\
\text { Keeping }\end{array}$ & $\begin{array}{l}2.56 \pm \\
0.66 \\
\end{array}$ & $\begin{array}{l}2.94 \pm \\
0.77 \\
\end{array}$ & $\begin{array}{l}2.50 \pm \\
0.76 \\
\end{array}$ & $\begin{array}{l}2.92 \pm \\
0.87 \\
\end{array}$ & $\begin{array}{l}2.17 \pm \\
0.83 \\
\end{array}$ & $\begin{array}{l}2.95 \pm \\
0.82\end{array}$ & $\begin{array}{l}2.58 \pm \\
0.69\end{array}$ & $\begin{array}{l}2.12 \pm \\
0.78\end{array}$ & $\begin{array}{l}2.84 \pm \\
0.82\end{array}$ & 2.97 & $0.004^{3}$ \\
\hline $\begin{array}{l}\text { Tracking } \\
\text { Health Issues }\end{array}$ & $\begin{array}{l}2.89 \pm \\
1.09\end{array}$ & $\begin{array}{l}3.31 \pm \\
0.84\end{array}$ & $\begin{array}{l}2.76 \pm \\
0.86\end{array}$ & $\begin{array}{l}3.04 \pm \\
0.88\end{array}$ & $\begin{array}{l}3.09 \pm \\
0.62\end{array}$ & $\begin{array}{l}3.37 \pm \\
0.95\end{array}$ & $\begin{array}{l}2.84 \pm \\
0.98\end{array}$ & $\begin{array}{l}2.57 \pm \\
0.80\end{array}$ & $\begin{array}{l}2.94 \pm \\
0.71\end{array}$ & 1.52 & 0.152 \\
\hline $\begin{array}{l}\text { Talking } \\
\text { with Providers }\end{array}$ & $\begin{array}{l}4.27 \pm \\
0.80\end{array}$ & $\begin{array}{l}3.80 \pm \\
1.22\end{array}$ & $\begin{array}{l}4.07 \pm \\
1.12\end{array}$ & $\begin{array}{l}4.22 \pm \\
1.06\end{array}$ & $\begin{array}{l}3.90 \pm \\
1.24\end{array}$ & $\begin{array}{l}4.47 \pm \\
0.73\end{array}$ & $\begin{array}{l}4.24 \pm \\
0.83\end{array}$ & $\begin{array}{l}4.30 \pm \\
0.84\end{array}$ & $\begin{array}{l}4.31 \pm \\
0.90\end{array}$ & 0.76 & 0.63 \\
\hline $\begin{array}{l}\text { Managing } \\
\text { Daily Activities }\end{array}$ & $\begin{array}{l}4.03 \pm \\
0.80\end{array}$ & $\begin{array}{l}4.49 \pm \\
0.54\end{array}$ & $\begin{array}{l}3.85 \pm \\
0.89\end{array}$ & $\begin{array}{l}4.20 \pm \\
0.91\end{array}$ & $\begin{array}{l}3.56 \pm \\
0.87\end{array}$ & $\begin{array}{l}4.53 \pm \\
0.58\end{array}$ & $\begin{array}{l}4.19 \pm \\
0.71\end{array}$ & $\begin{array}{l}3.20 \pm \\
1.40\end{array}$ & $\begin{array}{l}4.14 \pm \\
0.92\end{array}$ & 3.97 & $<0.001^{4}$ \\
\hline
\end{tabular}

G\&D: Growth \& Development; BMT: Bone Marrow Transplantation; Pulmo.: Pulmonology; Onco.: Oncology;

MMC: Myelomeningocele; DBT: Diabetes; Gastro.: Gastroenterology; Neuro.: Neurology;

Liver Tx: Liver Transplantation.

* Analysis of Variance (ANOVA). 1 Neuro. < DBT, BMT, Onco.; 2 Neuro. < Onco., DBT, BMT; 3

Neuro. < DBT, BMT, Onco.; 4 Neuro. < DBT, BMT, Onco., Gastro., Liver Tx.

SD: Standard deviation.

\section{REFERENCES}

1. McPherson M, Arango P, Fox H, Lauver C, et al. A new definition of Children with Special Health Care Needs. Pediatrics 1998;102(1 pt 1):137-40.

2. Jiménez Domínguez R, Cavalcante MTL. Proceso de transición de hospital pediátrico a hospital de adultos en pacientes crónicos complejos del Hospital Sant Joan de Déu. Documentos de Trabajo Social 2013;52:166-213.

3. Carpi JM. Transición a los cuidados del adulto. Enfermedad Inflamatoria Intestinal al día 2012;11(3):187-95.

4. Ferris ME, Harward DH, Bickford K, Layton JB, et al. A clinical tool to measure the components of health-care transition from pediatric care to adult care: The UNC TR(x) ANSITIoN Scale. Ren Fail 2012;34(6):744-53.

5. De Cunto CL. Transición en la atención médica, de la pediatría a la medicina del adulto. Arch Argent Pediatr 2012;110(4);341-7.

6. American Academy of Pediatrics, American Academy of Family Physicians, American College of PhysiciansAmerican Society of Internal Medicine. A consensus statement on health care transitions for young adults with special health care needs. Pediatrics 2002;110(6 pt 2):1304-6.

7. American Academy of Pediatrics, American Academy of Family Physicians, American College of Physicians, Transitions Clinical Report Authoring Group. Supporting the health care transition from adolescence to adulthood in the medical home. Pediatrics 2011;128 (1):182-200.

8. Zhang LF, Ho JS, Kennedy SE. A systematic review of the psychometric properties of transition readiness assessment tools in adolescents with chronic disease. BMC Pediatr 2014,14:4.

9. SawickiGS,Lukens-BullK, Yin X,Demars N, etal.Measuring the transition readiness of youth with special healthcare needs: Validation of the TRAQ- Transition Readiness Assessment Questionnaire. JPediatr Psychol 2011;36(2):16071.

10. Wood DL, Sawicki GS, Miller MD, Smotherman C et al. The Transition Readiness Assessment Questionnaire (TRAQ): its factor structure, reliability, and validity. Acad Pediatr 2014;14(4):415-22.

11. INDEC. La pobreza en la Argentina. Serie Estudios $N^{\circ} 1$. Buenos Aires: INDEC, 1984.

12. Terwee CB, Bot SD, de Boer MR, van der Windt DA, et al. Quality criteria were proposed for measurement properties of health status questionnaires. JClin Epidemiol 2007;60(1):3442.

13. Roizen M, Rodríguez S, Bauer G, Medin G, et al. Initial validation of the Argentinean Spanish version of the PedsQL4.0Generic CoreScales in children and adolescents with chronic diseases: acceptability and comprehensibility in low-income settings. Health Qual Life Outcomes 2008;6:59. 


\section{ANNEX}

Patient's Name:

Date of Birth:

Today's date

\section{Transition Readiness Assessment Questionnaire (TRAQ)}

Directions to Youth: Please check the box that best describes your skill level in the following areas that are important for transition to adult health care. There is no right or wrong answer and your answers will remain confidential and private.

Directions to Parents/Caregivers: If your youth or young adult is unable to complete the tasks below on their own, please check the box that best describes your skill level.

Check here if you are (a parent/a caregiver) completing this form.

\begin{tabular}{|c|c|c|c|c|c|}
\hline & $\begin{array}{l}\text { No, I don't } \\
\text { know how }\end{array}$ & $\begin{array}{l}\text { No, but I } \\
\text { want to } \\
\text { learn }\end{array}$ & $\begin{array}{l}\text { No, but } \\
\text { I am } \\
\text { learning } \\
\text { to do this }\end{array}$ & $\begin{array}{l}\text { Yes, I } \\
\text { have } \\
\text { started } \\
\text { doing this } \\
\end{array}$ & $\begin{array}{l}\text { Yes, I } \\
\text { always do } \\
\text { this when } \\
\text { I need to } \\
\end{array}$ \\
\hline \multicolumn{6}{|l|}{$\begin{array}{l}\text { Managing Medication (for patients who have taken or are } \\
\text { taking medication) }\end{array}$} \\
\hline \multicolumn{6}{|l|}{ 1. Do you fill a prescription if you need to? } \\
\hline \multicolumn{6}{|l|}{$\begin{array}{l}\text { 2. Do you know what to do if you are having a bad reaction to } \\
\text { your medication (for example: allergic reaction, diarrhea due } \\
\text { to medication)? }\end{array}$} \\
\hline \multicolumn{6}{|l|}{ 3. Do you take your medications correctly and on your own? } \\
\hline \multicolumn{6}{|l|}{ 4. Do you reorder your medications before they run out? } \\
\hline \multicolumn{6}{|l|}{ Appointment Keeping } \\
\hline \multicolumn{6}{|l|}{ 5. Do you call the doctor's office to make appointments? } \\
\hline \multicolumn{6}{|l|}{$\begin{array}{l}\text { 6. Do you keep track of specialist referrals, check-ups or } \\
\text { laboratory test results? }\end{array}$} \\
\hline \multicolumn{6}{|l|}{ 7. Do you arrange your ride to your medical appointments? } \\
\hline \multicolumn{6}{|l|}{$\begin{array}{l}\text { 8. Do you contact your doctor if you notice unusual changes } \\
\text { in your health (For example: allergic reactions, etc.)? }\end{array}$} \\
\hline \multicolumn{6}{|l|}{$\begin{array}{l}\text { 9. Do you know how to apply for health insurance if you lose } \\
\text { your current one? }\end{array}$} \\
\hline \multicolumn{6}{|l|}{$\begin{array}{l}\text { 10. Do you know what benefits are covered by your health } \\
\text { insurance, } \mathrm{HMO} \text {, etc.? }\end{array}$} \\
\hline \multicolumn{6}{|l|}{$\begin{array}{l}\text { 11. Do you manage your own money and pay your household } \\
\text { expenses (For example: use debit/credit card, etc.)? }\end{array}$} \\
\hline \multicolumn{6}{|l|}{ Tracking Health Issues } \\
\hline \multicolumn{6}{|l|}{$\begin{array}{l}\text { 12. Can you fill out any form in relation to your medical } \\
\text { history, including a list of your allergies? }\end{array}$} \\
\hline \multicolumn{6}{|l|}{$\begin{array}{l}\text { 13. Do you record your medical or other appointments in any } \\
\text { way (organizer, list, cell phone, etc.)? }\end{array}$} \\
\hline \multicolumn{6}{|l|}{$\begin{array}{l}\text { 14. Do you make a list of questions before you go to your } \\
\text { doctor's visit? }\end{array}$} \\
\hline \multicolumn{6}{|l|}{$\begin{array}{l}\text { 15. Do you get financial help from any institution (subsidy, } \\
\text { pension, support, etc.\}? }\end{array}$} \\
\hline \multicolumn{6}{|l|}{ Talking with Providers } \\
\hline \multicolumn{6}{|l|}{$\begin{array}{l}\text { 16. Do you tell your doctor or nurse about what you are } \\
\text { feeling? }\end{array}$} \\
\hline \multicolumn{6}{|l|}{$\begin{array}{l}\text { 17. Do you answer the questions asked by the doctor, nurse } \\
\text { or health team staff? }\end{array}$} \\
\hline \multicolumn{6}{|l|}{ Managing Daily Activities } \\
\hline \multicolumn{6}{|l|}{ 18. Do you help plan or prepare meals? } \\
\hline \multicolumn{6}{|l|}{$\begin{array}{l}\text { 19. Do you keep your room/home clean and/or clear the } \\
\text { table and/or do the dishes after meals? }\end{array}$} \\
\hline $\begin{array}{l}\text { 20. Do you use your neighborhood stores (For example: } \\
\text { grocery store, pharmacy store)? }\end{array}$ & & & & & \\
\hline
\end{tabular}

(C) Wood, Sawicki, Reiss \& Livingood, 2012 